\title{
Immune-Enhancing Effect of the Korean Natural Medicine WooKiEum
}

\author{
Hye-Young ShIN, ${ }^{a, b}$ Tae-Yong SHIN, ${ }^{c}$ Sang-Wan Seo, ${ }^{b}$ Hyo-Jin An, ${ }^{a, b}$ Yong-Taek Kwon, ${ }^{d}$ \\ Bong-Keun SonG, ${ }^{d}$ Eon-Jeong LeE, ${ }^{d}$ Sung-Hoon KIM, ${ }^{e}$ Yun-Kyung KIM, ${ }^{b}$ \\ Seung-Heon Hong, ${ }^{b}$ and Hyung-Min $\mathrm{KIM}^{*}, a$ \\ ${ }^{a}$ Department of Pharmacology, College of Oriental Medicine, Kyung Hee University; 1 Hoegi-Dong, Dongdaemun-Gu, \\ Seoul, 130-701, South Korea: ${ }^{b}$ College of Pharmacy, Wonkwang University; Iksan Jeonbuk 570-749, South Korea: \\ ${ }^{c}$ College of Pharmacy, Woosuk University; Jeonju, Jeonbuk, 565-701, South Korea: ${ }^{d}$ College of Oriental Medicine, \\ Wonkwang University; Iksan, Jeonbuk, 570-749, South Korea: and ${ }^{e}$ Graduate School of East-West Medical Science, \\ Kyunghee University; 1 Seochunri Kiheungeup Yongin 449-701, South Korea. \\ Received January 7, 2004; accepted April 30, 2004
}

\begin{abstract}
WooKiEum (WKE) has been used for the purpose of the development of increased immune-system strength in Korea. In the present study, we examined the anti-immobility effect of WKE on the forced swimming test (FST), and then measured blood biochemical parameters related to fatigue: glucose (Glc), blood urea nitrogen (BUN), lactic dehydrogenase (LDH), creatinine, and total protein (TP). WKE $(0.1,1 \mathrm{~g} / \mathrm{kg})$ was administered orally to mice for $7 \mathrm{~d}$. After $\mathbf{2 d}$, the immobility time was decreased in the WKE-administered group. After $7 \mathrm{~d}$, the immobility time was significantly decreased in the WKE-administered group $(64.6 \pm 9.0 \mathrm{~s}$ for $0.1 \mathrm{~g} / \mathrm{kg})$ in comparison with the control group $(101.3 \pm 32.7 \mathrm{~s})$. In addition, amount of Glc in the blood serum was increased, whereas the contents of BUN, LDH and TP decreased in the WKE-administered group. Next, we investigated the effect of WKE on the production of cytokines in a human T-cell line, MOLT-4 cells and mouse peritoneal macrophages. WKE (1 mg/ml) significantly increased interferon (IFN)- $\gamma$ and TNF- $\alpha$ production compared with the media control (about 2.2-fold for IFN- $\gamma$, about 1.7-fold for TNF- $\alpha, p<0.05$ ) after $24 \mathrm{~h}$. WKE increased the protein expression of IFN- $\gamma$ in MOLT-4 cells. These results suggest that WKE may be useful in immune function improvement.
\end{abstract}

Key words WooKiEum; forced swimming test; cytokine; immune function improvement

WooKiEum (WKE, 右歸飲), a traditional Korean medicine, has been used for the purpose of the development of physical strength, especially for those who have suffered from severe fatigue, headache, unrefreshing sleep, muscle pain, and multi-joint pain. ${ }^{1)}$ Although WKE has long been used effectively in treating these symptoms, its pharmacological mechanism has not been defined.

The forced swimming test (FST) is one of the most commonly used animal models of behavioral despair, and has been used extensively as a pre-clinical diagnostic tool for the assessment of novel anti-depressants. ${ }^{2,3)}$ It has been reported that FST exposure produces alterations in both cellular and noncellular immunity. ${ }^{4)}$ FST exposure caused a reduction in the percentage of lymphocytes and an increase in the percentage of neutrophils in the peripheral blood, and there was a significant but transient suppression of both phytohemagglutinin and concanavalin A-induced lymphocyte proliferation 15 min following FST exposure. ${ }^{5,6)}$ FST exposure produced a variety of time-dependent neurochemical, endocrine, and immune alterations in the rat. ${ }^{6}$ )

FST is used to examine whether a certain agent has an anti-fatigue effect, ${ }^{7-10}$ and is also used as an endurance test. $^{11,12)}$ Blood urea nitrogen (BUN), creatine kinase (CK), lactic dehydrogenase (LDH), glucose (Glc) and total protein (TP) are blood biochemical parameters related to fatigue. Exercising muscles convert Glc to lactate. Lactate is released into the blood and is eventually taken up by the liver. The liver converts lactate back to Glc and releases Glc into the blood. This Glc is then taken up by resting muscles, red blood cells, and other tissues. Energy for exercise is derived initially from the breakdown of glycogen, and later from circulating Glc released by the liver and from non-esterified fatty acids. ${ }^{13)}$ As is commonly known, the Glc level is decreased immediately after exercise. The BUN test is a routine test used primarily to evaluate renal function. Urea is formed in the liver as the end product of protein-metabolism. During digestion, protein is broken down into amino acids. Amino acids contain nitrogen, which is removed as $\mathrm{NH}^{+}$(ammonium ion), while the rest of molecule is used to produce energy or other substances needed by the cell. Serum CK and $\mathrm{LDH}$ are known to be accurate indicators of muscle damage. ${ }^{14,15)}$ The normal function of CK in cells is to add a phosphate group to creatine, turning it into the high-energy molecule phosphocreatine. Phosphocreatine is burned as a quick source of energy by cells. However, the normal function of CK isn't as relevant, in this case, as what happens to CK when muscle is damaged. During the process of muscle degeneration, muscle cells break open and their contents find their way into the bloodstream. Because most of the $\mathrm{CK}$ in the body normally exists in muscle, an increase in the amount of $\mathrm{CK}$ in the blood indicates that muscle damage has occurred, or is occurring. LDH catalyzes the interconversion of pyruvate and lactate. TP is a rough measure of serum protein. Protein measurements can reflect nutritional state, kidney disease, liver disease, and many other conditions. Enzymes, some hormones, hemoglobin, LDL, fibrinogen, and immunoglobulins are some examples of proteins. ${ }^{13)}$

Immunoregulatory cytokines play an important role in determining the nature and strength of an immune response. ${ }^{16,17)}$ Cytokines have historically been classified as Th1 types such as interleukin (IL)-2, interferon (IFN)- $\gamma$ or Th2 type IL-4, IL-5, IL-6 based on studies originally involving cloned murine $\mathrm{CD}^{+}{ }^{+} \mathrm{T}$ cell subsets. ${ }^{18,19)} \mathrm{Th} 1$ type cytokines promote cell-mediated immunity. Th2 cytokines pri- 
marily facilitate the development of humoral immune responses. ${ }^{20,21)}$ IFNs are among the cytokines that are involved in the host defense against viral infections. There are three major classes of human IFNs: interferon- $\alpha$ produced by leukocytes, interferon- $\beta$ produced by fibroblasts, and interferon- $\gamma$ produced by $\mathrm{T}$ cells. IFN- $\gamma$ induces B lymphocytes to switch from immoglobulin (Ig) M to IgG2a and IgG3 (opsonizing and complement-fixing subclasses). As described above, various cytokines such as IFN- $\gamma$, IL-2, IL-4, and tumor necrosis factor (TNF)- $\alpha$ are related to immune reactions, directly or indirectly.

The macrophage is involved in many different processes such as tissue remodeling during embryogenesis, wound repair, removal of damaged or senescent cells subsequent to injury or infection, haemopoiesis and homeostasis. Another function of macrophages is to provide a defense line against microbial invasion and to recognize and kill tumor cells. Macrophages can accomplish this in a direct manner, involving the release of products such as oxygen radicals and TNF$\alpha$ that are harmful to microorganisms or cancer cells. ${ }^{22)}$ On the other hand, they play an indirect role in these anti-microbial or anti-tumor activities by the secretion of cytokines $(e . g$. IL-12) or by antigen processing and presentation, thereby regulating the immune system. ${ }^{23}$ )

In the present study, we examined the anti-immobility effects of WKE and the contents of BUN, CK, LDH, Glc and $\mathrm{TP}$ in the blood serum. To investigate the effect of WKE on the production of cytokines, we analyzed the production of IFN- $\gamma$, IL- 2 , IL- 4 and TNF- $\alpha$ on the WKE treated MOLT- 4 cells and mouse peritoneal macrophages.

\section{MATERIALS AND METHODS}

Reagents Avidin-peroxidase and 2'-AZINO-bis (3-ethylbenzithiazoline-6-sulfonic acid) tablet substrate were purchased from Sigma (St. Louis, MO, U.S.A.). RPMI 1640, ampicillin, streptomycin and fetal bovine serum (FBS) were purchased from Gibco BRL (Grand Island, NY, U.S.A.). Anti-human IL-2, IL-4, IFN- $\gamma$ biotinylated anti-human IL-2, IL-4, IFN- $\gamma$ and recombinant (r) human IL-2, IL-4, IFN- $\gamma$ were purchased from R\&D Systems (Minneapolis, MN, U.S.A.). Anti-human TNF- $\alpha$, biotinylated anti-human TNF$\alpha$ and human TNF- $\alpha$ were purchased from Pharmingen, U.S.A.

Preparation of WKE The plant materials were obtained from the Wonkwang Oriental Medicine Hospital (Jeonju, Jeonbuk), and authenticated by Professor BK Song, College of Oriental Medicine, Wonkwang University. A voucher specimen (number 01-03-356) was deposited at the Herbarium of the College of Pharmacy, Wonkwang University. An extract of WKE was prepared by decocting the dried prescription of herbs with boiling distilled water. The duration of decoction was about $3 \mathrm{~h}$. The decoction was filtered, lyophilized and maintained at $4{ }^{\circ} \mathrm{C}$. The yield of extraction was about $14 \%(\mathrm{w} / \mathrm{w})$. The daily dose of WKE was $2 \mathrm{mg}$ per $20 \mathrm{~g}$ of mouse, which corresponds to $6 \mathrm{~g}$ for a man $(60 \mathrm{~kg})$. The WKE water extract powder was dissolved in sterile saline $(50 \mathrm{mg} / \mathrm{ml})$. The ingredients of WKE include $20 \mathrm{~g}$ of Rehmanniae Radix, $8 \mathrm{~g}$ of Dioscoreae Rhizoma, Lycii Fructus, Eucommiae Cortex, $4 \mathrm{~g}$ of Corni Fructus, Aconiti Tuber, Cinnamomi Cortex, and Glycyrrhizae Radix.
Animals The original stock of male ICR mice (15$20 \mathrm{~g}$ ) were purchased from the Daehan Biolink Co. (Daejeon, Korea), and were housed at a room temperature of $23 \pm 1^{\circ} \mathrm{C}$ with a 12/12 h light-dark cycle (lights on from 6:00 am to 6:00 pm). Food and water were available ad libitum. ICR mice were killed in accordance with National Institutes of Health animal care and use guidelines.

FST For $6 \mathrm{~min}$ of the forced swimming test, the duration of immobility was measured, as previously described by Porsolt and co-workers. ${ }^{24)}$ The apparatus consisted of two Plexiglas cylinders (height: $25 \mathrm{~cm}$, diameter: $10 \mathrm{~cm}$ ) placed side by side in a Makrolon cage filled with water $(10 \mathrm{~cm}$ height) at $23-25^{\circ} \mathrm{C}$. Two mice were tested simultaneously for a $6-$ min period inside vertical Plexiglas cylinders; a nontransparent screen placed between the two cylinders prevented the mice from seeing each other. The total duration of immobility, after a delay of $2 \mathrm{~min}$, was measured during a period of $4 \mathrm{~min}$. Each mouse was considered to be immobile when it ceased struggling and remained floating motionless in the water, making only those movements necessary to keep its head above water.

Preparation and Ingredient Analysis of Blood Serum Mice were anesthetized with an intraperitoneal injection of ketamine $(80 \mathrm{mg} / \mathrm{kg})$ and xylazine $(4 \mathrm{mg} / \mathrm{kg})$. After anesthetization, blood was withdrawn from the heart of forced swimming-treated mice into syringes. Then, serum was prepared by centrifugation at $3000 \mathrm{rpm}$ at $4{ }^{\circ} \mathrm{C}$ for $10 \mathrm{~min}$. The contents of BUN, CK, LDH, Glc and TP were determined by autoanalyzer (Hitachi 747, Hitachi, Japan).

MOLT-4 Cell Culture T cell line MOLT- 4 cells were grown in RPMI 1640 medium (Gibco BRL, U.S.A.) supplemented with $10 \%$ fetal bovine serum (JRH BIOSCIENCE, U.S.A.), $100 \mathrm{U} / \mathrm{ml}$ penicillin and $100 \mu \mathrm{g} / \mathrm{ml}$ streptomycin at $37^{\circ} \mathrm{C}$ in the presence of $5 \% \mathrm{CO}_{2}$.

Peritoneal Macrophage Culture TG-elicited macrophages were harvested $3 \mathrm{~d}$ after an intraperitoneal injection of $2.5 \mathrm{ml} \mathrm{TG}$ to mice, and isolated, as reported previously. ${ }^{25)}$ Using $8 \mathrm{ml}$ of HBSS, which contained $10 \mathrm{U} / \mathrm{ml}$ heparin, performed peritoneal lavage was performed. Then, the cells were distributed in DMEM, which was supplemented with $10 \%$ heat-inactivated FBS, in 4-well tissue culture plates $\left(3 \times 10^{5}\right.$ cells/well $)$ which were incubated for $3 \mathrm{~h}$ at $37^{\circ} \mathrm{C}$ in an atmosphere of $5 \% \mathrm{CO}_{2}$. These were then washed 3 times with HBSS to remove non-adherent cells, and equilibrated with DMEM that contained 10\% FBS before treatment.

Enzyme-Linked Immunosorbent Assay (ELISA) of Cytokines Sandwich ELISA for IFN- $\gamma$, IL-2, IL-4 and TNF- $\alpha$ was carried out in duplicate in 96-well ELISA plates (Nunc, Denmark) coated with each of $100 \mu$ l aliquots of anti-human IFN- $\gamma$, IL-2, IL-4 and TNF- $\alpha$ monoclonal antibodies at $1.0 \mu \mathrm{g} / \mathrm{ml}$ in PBS at $\mathrm{pH} 7.4$, followed by incubation overnight at $4{ }^{\circ} \mathrm{C}$. The plates were washed in PBS containing $0.05 \%$ Tween-20 (Sigma, St. Louis, MO, U.S.A.) and blocked with PBS containing $1 \% \mathrm{BSA}, 5 \%$ sucrose and $0.05 \% \mathrm{NaN}_{3}$ for $1 \mathrm{~h}$. After additional washes, sample or IFN- $\gamma$, IL-2, IL-4 or TNF- $\alpha$ standards were added and incubated at $37^{\circ} \mathrm{C}$ for $2 \mathrm{~h}$. After $2 \mathrm{~h}$ incubation at $37^{\circ} \mathrm{C}$, the wells were washed, then each of $0.2 \mu \mathrm{g} / \mathrm{ml}$ of biotinylated anti-human IFN- $\gamma$, IL-2, IL-4 or TNF- $\alpha$ were added and again incubated at $37^{\circ} \mathrm{C}$ for $2 \mathrm{~h}$. After washing the wells, avidin-peroxidase was added, and the plates were incubated for $20 \mathrm{~min}$ at $37^{\circ} \mathrm{C}$. Wells were 
again washed and ABTS substrate was added. Color development was measured at $405 \mathrm{~nm}$ using an automated microplate ELISA reader. A standard curve was run on each assay plate using recombinant IFN- $\gamma$, IL-2, IL- 4 and TNF- $\alpha$ in serial dilutions.

Western Blot Analysis Cell extracts were prepared by a detergent lysis procedure. Cells $\left(5 \times 10^{6}\right.$ cells $)$ were scraped, washed once with PBS, and resuspended in lysis buffer. Samples were vortexed for lysis for a few seconds every $15 \mathrm{~min}$ at $4{ }^{\circ} \mathrm{C}$ for $1 \mathrm{~h}$, and centrifuged at $15000 \times \mathrm{g}$ for $5 \mathrm{~min}$ at $4{ }^{\circ} \mathrm{C}$. Samples were heated at $95^{\circ} \mathrm{C}$ for $5 \mathrm{~min}$, and briefly cooled on ice. Following the centrifugation at $15000 \times \boldsymbol{g}$ for $5 \mathrm{~min}$, $50 \mu \mathrm{l}$ aliquots were resolved by $12 \%$ SDS-PAGE. Resolved proteins were transferred overnight to a nitrocellulose membrane in $25 \mathrm{~mm}$ Tris, $\mathrm{pH} 8.5,0.2 \mathrm{~mm}$ glycerin, and $20 \%$ methanol at $25 \mathrm{~V}$. Blots were blocked for at least $2 \mathrm{~h}$ with $1 \times$ TBST containing $10 \%$ nonfat dry milk. Protein levels were analyzed essentially according to the manufacturer's instructions.

HPLC Analysis The chromatographic system consisted of a pump (Waters Assoc., U.S.A.: 600E HPLC pump), a UV detector (Linear, UVIS 200 detector), an autosampler (Waters Assoc., U.S.A.: 717 plus autosampler), and a date modular (Waters Assoc., U.S.A.: 746computing integrator). A $\mu$ Bondapak $^{\mathrm{TM}} \mathrm{C}_{18}$ Waters column $(3.9 \mathrm{~mm} \times 300 \mathrm{~nm})$ was used. Water was used as the mobile phase. Detection of the peaks was made at $254 \mathrm{~nm}$, and the sensitivity was set at 1.0 AUFs. The injection volume was $20 \mu \mathrm{l}$ and the flow rate was $1.0 \mathrm{ml} / \mathrm{min}$. Standard solution was prepared by dissolving it in distilled water $(100 \mu \mathrm{g} / \mathrm{ml})$. The solution was filtered through a $0.45 \mu \mathrm{m}$ membrane filter and applied to HPLC.

Statistical Analysis The effects of WKE on immobility were evaluated by one-way analysis of variance (ANOVA), followed by Dunnett's test. Other results were analyzed by the independent $t$-test. The experiments shown are a summary of the data from at least three experiments. Values shown are the mean \pm standard error of the mean (S.E.M.). Differences were considered statistically significant when $p$ was less than 0.05 .

\section{RESULTS}

Effect of WKE on FST We investigated the anti-immobility effect of WKE on FST. After the first measurement of immobility time, the mice were divided into a control group and a WKE group to match the swimming time in each group. WKE $(0.1,1 \mathrm{~g} / \mathrm{kg})$ was orally administered to mice for 1 week. We measured the immobility time at days 2 and 7 after the administration of saline or WKE. The results indicated that the immobility time was decreased in the WKEadministered group in a comparison with the saline-administrated group (Fig. 1). After $2 \mathrm{~d}$, the immobility time was decreased in the WKE-administration group $(79.4 \pm 11.5 \mathrm{~s}$ for $0.1 \mathrm{~g} / \mathrm{kg}$ ) in comparison with the control group $(104.8 \pm$ $24.1 \mathrm{~s})$. After $7 \mathrm{~d}$, the immobility time was significantly decreased in the WKE-administration group $(64.6 \pm 9.0 \mathrm{~s}$ for $0.1 \mathrm{~g} / \mathrm{kg}$ ) in comparison with the control group $(101.3 \pm$ $32.7 \mathrm{~s})$. An apparent anti-immobility effect was observed following the administration of WKE at $0.1 \mathrm{~g} / \mathrm{kg}$ (Fig. 1).

Effect of WKE on Blood Biochemical Parameters after FST In order to clarify its mechanisms, we assessed the

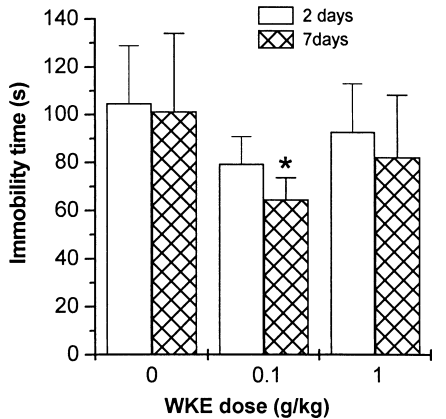

Fig. 1. Effect of WKE on FST

Immobility time was recorded for $6 \mathrm{~min}$ in the mice administered saline or WKE. Values are the mean \pm S.E.M. of duplicate determinations from five separate experiments. $* p<0.05$ : indicates significant difference from the saline group.

Table 1. Effect of WKE on Blood Biochemical Parameters after FST ${ }^{a}$ )

\begin{tabular}{lccc}
\hline \hline & Saline & $\begin{array}{c}\text { WKE } \\
(0.1 \mathrm{~g} / \mathrm{kg} / \mathrm{d})\end{array}$ & $\begin{array}{c}\mathrm{WKE} \\
(1 \mathrm{~g} / \mathrm{kg} / \mathrm{d})\end{array}$ \\
\hline Glc $(\mathrm{mg} / \mathrm{dl})$ & $246 \pm 12.1$ & $295.5 \pm 39.5$ & $303 \pm 15.3^{*}$ \\
LDH (U/l) & $1005 \pm 159.0$ & $980.0 \pm 20.0$ & $917.0 \pm 189$ \\
$\mathrm{BUN}(\mathrm{mg} / \mathrm{dl})$ & $32.3 \pm 1.0$ & $22.6 \pm 0.8$ & $19.6 \pm 0.7^{*}$ \\
$\mathrm{CK}(\mathrm{mg} / \mathrm{dl})$ & $0.7 \pm 0.0$ & $0.5 \pm 0.0$ & $0.6 \pm 0.0$ \\
$\mathrm{TP}(\mathrm{g} / \mathrm{dl})$ & $5.3 \pm 0.3$ & $4.5 \pm 0.0$ & $4.7 \pm 0.10^{*}$
\end{tabular}

a) WKE $(1,0.1 \mathrm{~g} / \mathrm{kg}$ for $7 \mathrm{~d})$ was administered orally to the mice and then we measured the levels of Glc, LDH, BUN, CK and TP in the serum. Each level was determined by the autoanalyzer. Values are the mean \pm S.E.M. of duplicate determinations from five separate experiments. $* p<0.05$ versus saline-administrated group.

levels of several blood biochemical parameters in mice after FST. Blood was withdrawn from the heart of forced swimming-treated mice into syringes, and blood serum was prepared by centrifugation. The contents of BUN, CK, LDH, Glc, TP were determined by the autoanalyzer. As shown in Table 1, when WKE $(0.1,1 \mathrm{~g} / \mathrm{kg}, 7 \mathrm{~d})$ was administered orally to mice, the Glc level increased, and the BUN, LDH, TP level tended to decrease in the WKE-administrered group. However, the CK level showed no change compared with that of the saline-administered mice.

Effect of WKE on the Production of IFN- $\gamma$ and IL-2, IL-4 in MOLT-4 Cells To assess the effects of WKE on the production of various cytokines, the MOLT- 4 cells were treated with various concentrations of WKE for $24 \mathrm{~h}$. The levels of IL-2, IL-4 and IFN- $\gamma$ were analyzed by the ELISA method. As shown in Fig. $2 \mathrm{~A}$, WKE $(0.79 \pm 0.24 \mathrm{ng} / \mathrm{ml}$ at $1 \mathrm{mg} / \mathrm{ml})$ significantly increased the IFN- $\gamma$ production compared with the media control $(0.35 \pm 0.04 \mathrm{ng} / \mathrm{ml})$. WKE did not affect the production of IL-2 and IL-4 compared with the media control (Figs. 2B, C).

Effect of WKE on the Production of TNF- $\alpha$ in Peritoneal Macrophages We next examined whether WKE was able to stimulate potential mediators such as TNF- $\alpha$ in isolated mouse peritoneal macrophages. Mouse peritoneal macrophages were cultured with rIFN- $\gamma$ for $6 \mathrm{~h}$, then stimulated with $0.01-1 \mathrm{mg} / \mathrm{ml}$ concentrations of WKE for $24 \mathrm{~h}$. As shown in Fig. 3, WKE alone did stimulate the production of TNF- $\alpha$ (unstimulated cells, $0.82 \pm 0.04 \mathrm{ng} / \mathrm{ml}$; WKE $0.01 \mathrm{mg} / \mathrm{ml}, \quad 0.95 \pm 0.15 \mathrm{ng} / \mathrm{ml} ; \quad$ WKE $\quad 0.1 \mathrm{mg} / \mathrm{ml}, \quad 1.47 \pm$ $0.10 \mathrm{ng} / \mathrm{ml}$; WKE $1 \mathrm{mg} / \mathrm{ml}, 1.43 \pm 0.13 \mathrm{ng} / \mathrm{ml})$. The amount of TNF- $\alpha$ was significantly higher in the rIFN- $\gamma$ plus WKE treated cells, than in the rIFN- $\gamma$ treated cells (rIFN- $\gamma$, 

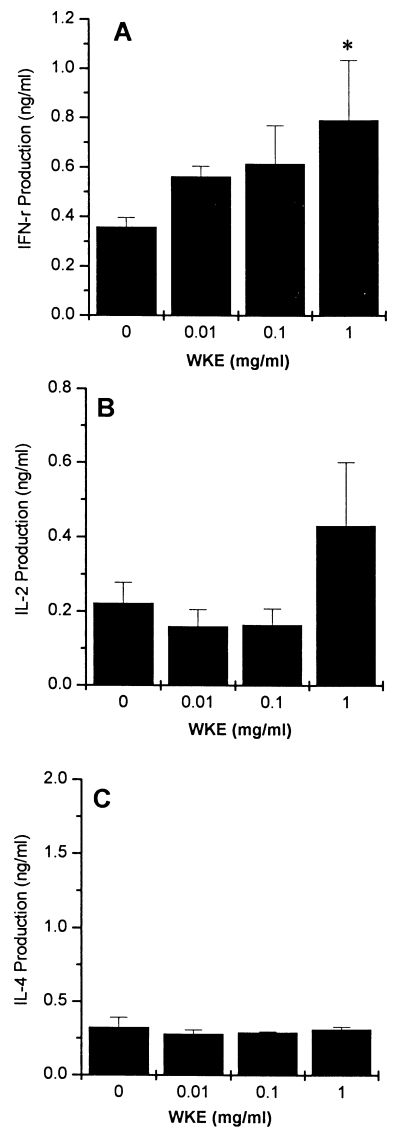

Fig. 2. Effect of WKE on IFN- $\gamma$ (A), IL-2 (B), IL-4 (C) Production in the MOLT-4 Cells

Culture supernatant was collected from untreated or WKE treated MOLT-4 cells, which were cultured for $24 \mathrm{~h}$. Cytokine levels in the culture supernatant were measured using ELISA. Values are the mean \pm S.E.M. of duplicate determinations from five separate experiments. $* p<0.05$; significantly different from the saline value.

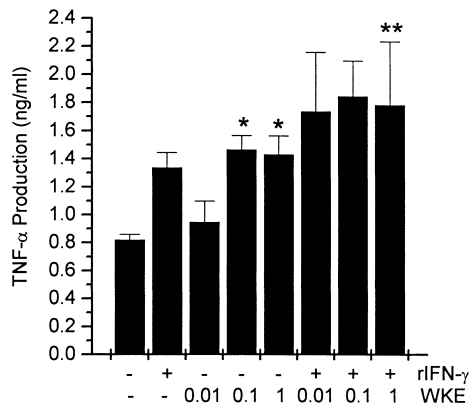

Fig. 3. Effect of WKE on TNF- $\alpha$ Production in the Mouse Peritoneal Macrophages

The cells $\left(3 \times 10^{5}\right.$ cells/well) were stimulated with rIFN- $\gamma$, WKE or WKE + rIFN- $\gamma$. TNF- $\alpha$ levels in the culture supernatant were measured using ELISA. Values are the mean \pm S.E.M. of duplicate determinations from five separate experiments. $* p<0.05$ is different from the unstimulated value. $* * p<0.05$ is different from rIFN- $\gamma$ treated value.

$1.13 \pm 0.11 \mathrm{ng} / \mathrm{ml} ; \mathrm{rIFN}-\gamma$ plus WKE $0.01 \mathrm{mg} / \mathrm{ml}, 1.74 \pm 0.42$; rIFN- $\gamma$ plus WKE $0.1 \mathrm{mg} / \mathrm{ml}, 1.84 \pm 0.25 \mathrm{ng} / \mathrm{ml} ; \mathrm{rIFN}-\gamma$ plus WKE $1 \mathrm{mg} / \mathrm{ml}, 1.78 \pm 0.45 \mathrm{ng} / \mathrm{ml})$.

Effect of WKE on IFN- $\gamma$ Protein Expression in MOLT4 Cells Finally, intracellular IFN- $\gamma$ protein levels of MOLT4 cells were determined by Western blot analysis (Fig. 4). Treatment of cells with WKE $(0.01,0.1,1 \mathrm{mg} / \mathrm{ml})$ dose-dependently increased IFN- $\gamma$ expression.

Characterization of the Principal Components of WKE

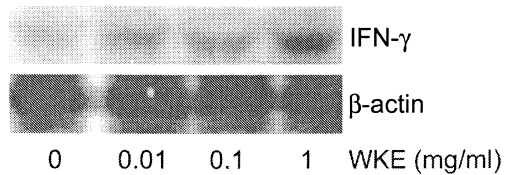

Fig. 4. Effect of WKE on IFN- $\gamma$ Expression in the MOLT-4 Cells

The protein extracts were prepared and samples were analyzed for IFN- $\gamma$ expression by western blotting.

$-1.0 .000 \mathrm{mV}$

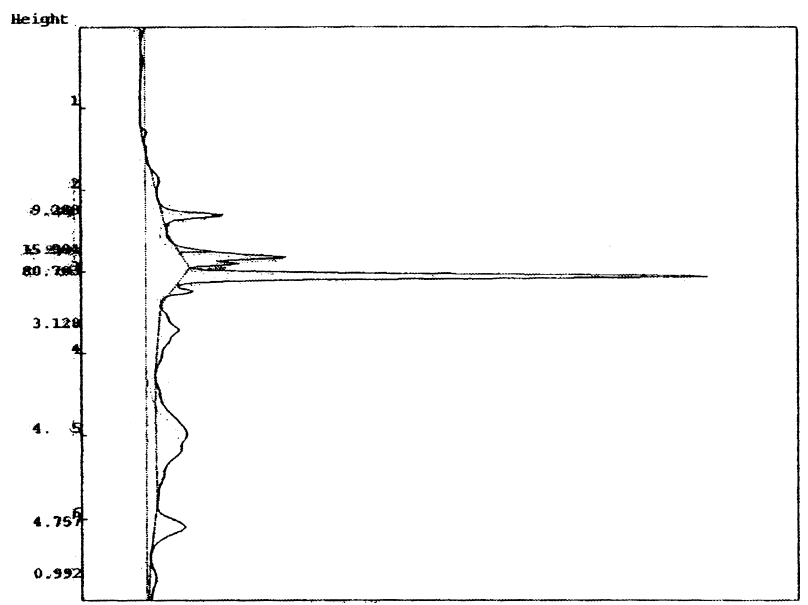

Fig. 5. HPLC Chromatogram of the WKE

A standard solution of WKE was prepared by dissolving it in distilled water $(10 \mathrm{mg} / 100 \mathrm{ml})$. The injection volume was $20 \mu \mathrm{l}$ and the detection was made at $254 \mathrm{~nm}$.

The WKE was analyzed by HPLC. A chromatogram of WKE is shown in Fig. 5. Peaks of the principal components have not yet been identified in this study.

\section{DISCUSSION}

In the present study, we showed that WKE decreased the immobility time in FST. WKE also strongly induced the production of IFN- $\gamma$ from MOLT- 4 and TNF- $\alpha$ from mouse peritoneal macrophages. Many psychotropic drugs have been screened using the FST. ${ }^{2,3)}$ Although many antidepressants attenuate FST-induced immobility, ${ }^{26}$ very little is known about the FST-induced immune alteration. Some studies have reported reduced neutrophil phagocytosis, impaired natural killer cell cytotoxic responses, and the suppression of lymphocyte proliferation and IL-2 production as a result of exposure to FST. ${ }^{27)}$ Many similar alterations in immune function have been reported in depressed patients. ${ }^{28,29)}$

There are some previous reports on the immune-enhancing effect of Korean natural preparations such as Herbkines, Bouum-Myunyuk-Dan, Cool-Cool. ${ }^{30-32)}$ Herbkines formula is a newly modified prescription composed of eight herbs for the purpose of the development of physical strength, especially for those who have suffered from wasting diseases, like cancer, in South Korea. ${ }^{30)}$ Cool-Cool is a water extract made from six herbal medicines. It has been reported that Cool-Cool inhibits inflammatory cytokine production and migration in mast cells. ${ }^{31)}$ It has been reported that BouumMyunyuk-Dan, composed of 16 herbs, has an immune-enhancing effect by increasing IL-2, IL-4 and IFN- $\gamma$ production in MOLT- 4 cells, and TNF- $\alpha$ and IL-12 in mouse peritoneal macrophages. ${ }^{32)}$ Wide variations between active ingredients 
can occur in the herbal medicine.

We assessed the levels of several blood biochemical parameters in mice after FST. The Glc level significantly increased, while the LDH level tended to decrease. LDH is known to be an accurate indicator of muscle damage, and catalyzes the interconversion of pyruvate and lactate. ${ }^{13,14)}$ Therefore, the LDH level increases immediately after exercise. Interestingly, in the present study, the LDH level was decreased by the administration of WKE. On the other hand, the Glc level decreased immediately after exercise. Our result showed that Glc level was increased by the administration of WKE. The TP level slightly decreased. These facts suggest that WKE may act as an energy source. However, the CK level showed no change compared with that of the saline-administered mice. In general, the swimming exercise is known to induce blood biochemical changes. ${ }^{30}$ ) The BUN, CK, LDH, Glc and TP are blood biochemical parameters related to fatigue. In the present study there were no significant changes in biochemical parameters, but the immobility times were significantly decreased after $7 \mathrm{~d}$ of application with WKE at $0.1 \mathrm{~g} / \mathrm{kg} / \mathrm{d}$. Although Glc, BUN, and TP levels were significantly changed with WKE at $1 \mathrm{~g} / \mathrm{kg} / \mathrm{d}$, the immobility times tended to recover to the values of the saline control. Even though the statistical difference was weak, the tendency of some changes was found in biochemical parameters after $7 \mathrm{~d}$ of application with WKE at $0.1 \mathrm{~g} / \mathrm{kg} / \mathrm{d}$. We think this change is related to the decrease of immobility time at $0.1 \mathrm{~g} / \mathrm{kg} / \mathrm{d}$. The immobility time at WKE $1 \mathrm{~g} / \mathrm{kg} / \mathrm{d}$ also showed a tendency to decrease $(92.8 \mathrm{~s}$ on the 2 nd day, $82.25 \mathrm{~s}$ on the 7 th day). These results indicate that fatigue metabolisms of mice were influenced by WKE administration. However, because we observed several inconsistent points among our data, further studies to clarify the detailed mechanisms involved in the anti-fatigue-like properties of WKE are necessary to support the present findings.

The invasion of phagocytic cells by intracellular pathogens induces the copious secretion of IL-12, which in turn stimulates IFN- $\gamma$ production. These two cytokines selectively drive the differentiation of Th1 development and inhibit Th2 responses. ${ }^{31)}$ An immune response can be broadly categorized into a cellular or humoral mediated response. The production of IL- 2 , IFN- $\gamma$, and TNF- $\alpha$ lead to a Th1-type cellular response, while the production of IL-4 and IL-6 lead to Th2type humoral immunity. Th1 cells play a role in inflammatory processes, macrophage activation and delayed sensitivity, whereas Th2 cells help B cells to synthesize antibodies. $^{32-34)}$ The activation of tumor antigen-specific Th and Tc cells or non-specific macrophages and natural killer cells using immunotherapeutic approaches may lead to the subsequent destruction of tumor tissue. ${ }^{31)}$ Previous reports have demonstrated that the induction of Th1-promoting cytokines, using specific adjuvants, can enhance anti-tumor immunity and can reduce or even prevent tumor growth. ${ }^{35)}$ Many cancer vaccines, particularly in combination with immune adjuvants, elicit strong cellular immune responses leading to the production of Th1 type cytokines such as IL-2, IFN- $\gamma$, TNF$\alpha{ }^{36)}$ IFN- $\gamma$ is also an important cytokine in the host defense against infection by viral and microbial pathogens. ${ }^{37)}$ IFN- $\gamma$ induces a variety of physiologically significant responses that contribute to immunity. TNF- $\alpha$ participated in the host defense against pathogens. TNF- $\alpha$ also modulated the immune response by triggering the production of a number of other regulatory cytokines such as IL-1, 6, IFNs, transforming growth factors, and granulocyte-monocyte colony stimulating factor. ${ }^{38)}$ Previously, we reported that Th2 cytokine levels were higher than Th1 cytokine levels in various diseases, including cerebral infarction, allergy and asthma. ${ }^{39,40)}$ In this study, we reported that WKE strongly increased the production and expression of IFN- $\gamma$, while it did not affect the production of IL- 2 and IL-4 in MOLT- 4 cells. Also, WKE increased the production of TNF- $\alpha$ in mouse peritoneal macrophages. There is no dose-dependency for the most part in the actions of WKE, except for IFN- $\gamma$ production and expression in MOLT- 4 cells. The aim of the cytokine study was to evaluate whether WKE had any pharmacological effects on the immune system, and WKE showed significant changes in some cytokine production. In spite of no dose-dependency, those changes are at least worth noticing as evidence of WKE affecting the immune system. The effective concentration on the cytokine production is actually too high, which means a possible application to patients is likely to be missing. We just believe that the results of this study may provide us with a clue as to the pharmacological function of the formula for future in vivo study.

We have examined the effect of WKE in the FST, and on the change of WKE-mediated cytokine production. Our results suggest that the decrease in immobility time caused by WKE administration in FST might be mediated through immune-enhancement. Because WKE decreased the immobility time in this test without stimulating motor activity, we postulated that WKE has a potential for inducing immune enhancement.

Acknowledgements This study was supported by Wonkwang University in 2003.

\section{REFERENCES}

1) Woo W. H., Jeong W. Y., J. Korean Oriental Medical Pathology, 3, 18-29 (1988).

2) Porsolt R. D., Anton G., Blavet N., Jalfre M., Eur. J. Pharmacol., 47, 379-391 (1978).

3) Connor T. J., Kelliher P., Shen Y., Harkin A., Kelly J. P., Leonard B. E., Pharmacol. Biochem. Behav., 65, 591-597 (2000).

4) Delbende C., Tranchand Bunel. D., Tarozzo G., Grino M., Oliver C., Mocaer E., Vaudry H., Eur. J. Pharmacol., 251, 245-251 (1994).

5) Connor T. J., Kelly J. P., Leonard B. E., Pharmacol. Biochem. Behav, 59, 171-177 (1998).

6) Connor T. J., Kelly J. P., Leonard B. E., Pharmacol. Biochem. Behav., 58, 961-967 (1997).

7) Dubovik B. V., Bogomazov S. D., Farmakol Toksikol, 2, 116-121 (1987).

8) Moriura T., Matsuda H., Kubo M., Biol. Pharm. Bull., 19, 62-66 (1996).

9) Deyama T., Nishibe S., Nakazawa Y., Acta Pharmacol. Sinica, 12, 1057-1070 (2001).

10) Kim K. M., Yu K. W., Kang D. H., Suh H. J., Phytother. Res., 7, 700702 (2002).

11) Novelli G. P., Falsini S., Bracciotti G., Pharmacol. Res., 2, 149-155 (1991).

12) Ozturk N., Husnu Can. Baser. K., Aydin S., Ozturk Y., Calis I., Phytother. Res., 7, 627-631 (2002).

13) Dorchy H., Rev. Med. Brux., 4, A211-A217 (2002).

14) Burr J. R., Reinhart G. A., Swenson R. A., Swaim S. E., Vaughn D. M., Bradley D. M., J. American Vet. Med. Assoc., 211, 175-179 (1997).

15) Coombes J. S., McNaughton L. R., J. Sports Med. Phys. Fitness, 3, 
$240-246(2000)$.

16) Abbas A. K., Murphy K. M., Sher A., Nature (London), 383, 787793 (1996).

17) Paul W. E., Seder R. A., Cell, 76, 241-251 (1994).

18) Mosmann T. R., Cherwinski H., Bond M. W., Giedlin M. A., Coffman R. L., J. Immunol., 136, 2348-2357 (1986).

19) Mosmann T. R., Coffman R. L., Annu. Rev. Immunol., 7, 145-173 (1989).

20) Carter L. L., Dutton R. W., Curr. Opin. Immunol., 8, 336-342 (1996).

21) Stephens R., Eisenbarth S. C., Chaplin D. D., Curr. Opin. Allergy Clin. Immunol., 2, 31-37 (2002).

22) Adams O. D., Hamilton T. A., "Molecular Basis of Macrophage Activation and Its Orgins," Oxford University Press, New York, 1992, pp. $75-114$.

23) Klimp A. H., de Vries E. G., Scherphof G. L., Daemen T., Crit. Rev. Oncol. Hematol., 44, 143-161 (2002).

24) Narumi S., Finke J. H., Hamilton T. A., J. Biol. Chem., 265, 70367041 (1990).

25) Porsolt R. D., Bertin A., Jalfre M., Arch. Int. Pharmacodyn. Ther., 229, 327-336 (1977)

26) Borsini F., Cesana R., Vidi A., Mennini T., Eur. J. Pharmacol., 203, 359-363 (1991).

27) Shu J., Stevenson J. R., Zhou X., Dev. Comp. Immunol., 17, 357-371
(1993).

28) Irwin M., Smith T. L., Gillin J. C., Life Sci., 41, 2127-2133 (1987).

29) Kronfol Z., House J. D., Acta Psychiatr. Scand., 80, 142-147 (1989).

30) Kumahara Y., Yano S., Ogihara T., Yamamoto M., Hata J., Hirayama M., Uchiyama J., Saito T., Sekiya M., Ito Y., Sakakibara T., Hara K., Yakuri To Chiryo, 17, 3633-3641 (1989).

31) Mackensen A., Lindemann A., Mertelsmann R., Cytokine Growth Factor Rev., 8, 119-128 (1997).

32) Romagnani S., Immunol. Today, 12, 256-257 (1991).

33) Parronchi P., Macchia D., Piccinni M. P., Biswas P., Simonelli C., Maggi E., Ricci M., Ansari A. A., Romagnari S., Proc. Natl. Acad. Sci. U.S.A., 88, 4538- 4542 (1991).

34) Zurawski G., De Vries J. E., Immunol. Today, 15, 19-26 (1994).

35) Dredge K., Marriott J. B., Todryk S. M., Dalgleish A. G., Cancer Immunol. Immunother, 51, 521-531 (2002).

36) Dalgleish A. G., Br. J. Cancer, 82, 1619-1624 (2002).

37) Samuel C. E., Clin. Microbiol. Rev., 14, 778-809 (2001).

38) Branellec D., Chouaib S., Pathol. Biol. (Paris), 39, 230-239 (1991).

39) Kim H. M., Shin H. Y., Jeong H. J., An H. J., Kim N. S., Chae H. J., Kim H. R., Song H. J., Kim K. Y., Baek S. H., Cho K. H., Moon B. S., Lee Y. M., J. Mol. Neurosci., 14, 191-196 (2000).

40) Jeong H. J., Kim B. S., Kim K. S., Kim H. M., Immunopharmacol. Immunotoxicol., 24, 265-274 (2002). 